\title{
AIS Faculty Familiarity And Perceptions Of AIS Journals
}

Thomas Tribunella, (E-mail: ttribunella@cob.rit.edu), Rochester Institute of Technology

\begin{abstract}
Much research has been published related to journal quality in fields such as accounting, finance, information systems, and management. In accounting, the sub-disciplines of auditing, financial, management, and tax have received attention in published papers. This study contributes to the literature by providing an in-depth study of AIS faculty familiarity and perceptions of AIS journals. I collected faculty perceptions about AIS journals from the American Accounting Association members of the Information Systems and Artificial Intelligence / Emerging Technology sections. The result is an AIS journal ranking that is substantially different than the rankings produced by other studies of accounting journals.
\end{abstract}

\section{INTRODUCTION}

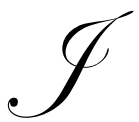

ournal ranking studies have focused on fields such as accounting, economics, management, and finance. The field of accounting is replete with general accounting journal rankings. This study contributes to the literature by providing an in-depth study of Accounting Information Systems (AIS) faculty familiarity and perceptions of AIS journals. The study defines familiarity as the journals that AIS faculty read and the journals where they publish.

Accounting Information Systems is a relatively new and interdisciplinary area in the field of accounting when compared with financial, managerial, auditing, governmental and tax accounting. AIS research is the combination of two disciplines, the study of accounting with the study of information systems (IS). AIS focuses on the collection, processing, reporting and storage of information related to the financial aspects of business events (Gelinas and Sutton 2002).

This study looks at faculty familiarity and perceptions of academic journals that are outlets for AIS research. The sample was taken from faculty that showed an interest in AIS through their section membership in the American Accounting Association. The results of this study should benefit professors that teach and research in this interdisciplinary area. A ranking of AIS journals could supply valuable insight during promotion, tenure and compensation decisions.

\section{LITERATURE REVIEW}

Several journal articles were reviewed to understand previous research conducted in the area of journal rankings and faculty perceptions of journals. A broad range of articles have addressed this issue. Two primary types of methodologies are used to rank journals: citation count and faculty perceptions. Both methodologies have inherent limitations.

Citation count involves summing the number of times a journal article is referenced in other publications. Citations are particularly difficult to count in AIS due to the interdisciplinary nature of the field. Samuels and Steinbart (2002) published a citation study in the area of AIS. They examined the number of times Journal of Information Systems (JIS) articles referenced other sources. They found that JIS articles reference a wide variety of sources including accounting, management information systems, computer science, management and business, education, and psychology journals. In addition, many AIS journals are not included in citation indexes. Other critics 
argue that citation studies favor popular authors and popular subjects that enjoy a halo effect (May 1967). For example, authors that write literature reviews (Woodward and Henson 1976) and authors that write methodological articles in established areas (Margolis 1967) tend to be cited more frequently.

Faculty rankings based on perceptions are subject to the biases and predispositions of respondents (Ballas and Theoharakis 2002). Hotard, Tanner and Manakyan (1996) conducted a study to understand the factors that shape faculty perceptions of journals. They found that factors such as technical level, type of review, acceptance rate, frequency of citations, and reputation of the editorial board may influence faculty perceptions of journals. Opinion studies can be influenced by sample bias, response bias and framing bias. Response bias occurs when the respondents to the research instrument differ significantly from the non-respondents. Sampling bias is the result when, the sample of individuals chosen to receive the research instrument does not represent the population being studied. Framing bias may arise in journal ranking studies when the list of journals is not inclusive or the journals are presented in a list that produces bias responses (ordering problems).

Journal ranking studies are controversial because they may delve into sensitive issues. Some faculty members express concern that journal rankings will commoditize academic productivity and reduce the diversity of scholarship (Gray, Guthrie and Parker 2002). Others argue that, the rigorously refereed research published by top ranked journals is the foundation of business education (Zimmerman 2001). Therefore, we need journal raking studies to identify the most selective research outlets.

In spite of the debates, many journals rankings based on faculty perceptions have been published. Coe and Weinstock (1983) surveyed 135 Association to Advance Collegiate Schools of Business (AACSB) accounting chairpersons. Howard and Nikolai (1983) took a random sample from the faculty listed in the Accounting Faculty Directory (Hasselback 1980 - 1981) that held a doctorate degree and worked at a U.S. educational institution. Hull and Wright (1990) also used a random sample of PhD, JD or LLM faculty listed in the Accounting Faculty Directory. Brown and Huefner (1994) surveyed associate and full professors at the top 40 MBA Programs listed in Business Week's Guide to the Best Business Schools.

Research that examines accounting journals generally under-represent information systems (IS) in their journal lists due to the interdisciplinary nature of IS journals (Baldwin, Morris and Scheiner 2000). However, Arnold (1993) studied AIS journals by surveying 504 accounting faculty who were members of the IS and Management Advisory Services (MAS) sections of the American Accounting Association (AAA). The participants were asked to rank 80 journals using the magnitude method (Howard and Nikolai 1983). Under the magnitude estimation procedure, respondents are asked to rank the relative value of a publication in a journal in relation to an anchor journal given a weight of 100 . A score of 150 would indicate that the journal was $50 \%$ better quality than the anchor journal.

Daigle and Arnold (2000) also studied AIS journal quality by asking the 25 top researchers in AIS to rank 45 journals. Using this data they produced a journal ranking as well as a list of institutions employing highly productive AIS researchers and a list of doctorial institutions graduating highly productive AIS scholars. Their sample size was relatively small and only representative of elite researchers, which limits generalization to the population of AIS faculty. In addition, the small number of journals framed by the survey excluded many AIS outlets such as the Review of Accounting Information Systems and The CPA Journal. In addition, the study did not control for journals that do not regularly publish AIS research such as the Journal of Accounting Research and the Journal of Accounting \& Economics.

Baldwin, Morris and Scheiner (2000) researched the question: Where do AIS researchers publish. The study produced a list of AIS outlets sub-divided into the following groups: high frequency, medium frequency and low frequency. However, the study did not rate journal quality. In addition, Doney and Eaton surveyed 316 AAA IS section senior faculty members. Senior faculty was defined as associate professors, full professors, deans, directors and chairs. The senior faculty rated journals on a scale of one to five. The respondents also ranked journals by identifying their choice for the top three ranked journals. Table 1 displays a summary of published papers that have ranked AIS journals based on faculty perceptions and resumes. 
Table 1: Literature Review of Published Studies That Have Ranked AIS Journals

\begin{tabular}{|l|c|c|c|c|c|}
\hline Authors & This Study (2004) & $\begin{array}{c}\text { Doney \& Eaton } \\
(2003)\end{array}$ & $\begin{array}{c}\text { Daigle \& Arnold } \\
(2000)\end{array}$ & $\begin{array}{c}\text { Baldwin, Morris \& } \\
\text { Scheiner (2000) }\end{array}$ & Arnold (1993) \\
\hline $\begin{array}{l}\text { Rumber of } \\
\text { Respondents }\end{array}$ & $\begin{array}{c}\text { 146 from the IS } \\
\text { and/ET AAA } \\
\text { sections }\end{array}$ & $\begin{array}{c}\text { AIS faculty in } \\
\text { Hasselback }\end{array}$ & $\begin{array}{c}25 \text { most } \\
\text { productive AIS } \\
\text { researchers }\end{array}$ & $\begin{array}{c}70 \text { from the AAA } \\
\text { IS section }\end{array}$ & $\begin{array}{c}138 \text { from the IS/MAS } \\
\text { AAA section }\end{array}$ \\
\hline Response Rate & $146 / 936=15.6 \%$ & $101 / 470=21.5 \%$ & $18 / 29=62.1 \%$ & $70 / 316=22.2 \%$ & $138 / 504=27.4 \%$ \\
Jumber of & 207 & 50 & 45 & 193 & 80 \\
\hline Ranking Method & $\begin{array}{c}\text { Percent who } \\
\text { ranked journal as } \\
\text { Most Prestigious, } \\
\text { Significant, } \\
\text { Creditable or Not } \\
\text { Appropriate for } \\
\text { AIS Research }\end{array}$ & $\begin{array}{c}\text { Scale from 1 } \\
\text { (lowest) to 5 } \\
\text { (highest) and top 3 } \\
\text { ranked journals }\end{array}$ & $\begin{array}{c}\text { Method Relative } \\
\text { to the Journal of } \\
\text { Information } \\
\text { Systems }\end{array}$ & $\begin{array}{c}\text { Magnitude } \\
\text { where AIS } \\
\text { published by } \\
\text { examining } \\
\text { resumes }\end{array}$ & $\begin{array}{c}\text { Magnitude Method } \\
\text { Relative to the } \\
\text { Journal of } \\
\text { Accountancy }\end{array}$ \\
\hline
\end{tabular}

In addition to reviewing previous studies, research methods were reviewed to select an appropriate survey method. The two most common forms of survey methods are telephone/interview surveys and mail surveys. Response rates for mail surveys are typically five to ten percent according to Alreck and Settle (1995). For this study, the mail survey was selected as it would be less intrusive, expensive and labor intensive.

\section{CONTRIBUTION TO THE LITERATURE AND RESEARCH QUESTIONS}

This study contributes to the literature in several ways. First, it includes an adjustment for two of the ranking lists by excluding the top ten journals that are perceived by respondents as not appropriate for AIS research. According to Stone (2002), the top five accounting journals ( $A R, A O S, C A R, J A E, J A R$, abbreviations are defined in the Appendix) only published six AIS papers from 1989 to 1998. Different and interesting results may be obtained when journals that do not regularly publish AIS related papers are excluded from the rankings.

The survey used in this study targeted the Information Systems (IS) and Artificial Intelligence / Emerging Technology (AI/ET) sections of the AAA. Therefore, the survey specifically aims at the domain of AIS and the individuals who are familiar with AIS journals. Accordingly, the survey results were completed by those who have informed opinions. Knowing how AIS journals are perceived by the peer group of faculty in the specific field should be helpful to AIS scholars. Finally, the respondents were asked to judge AIS journal quality, not overall journal quality. This helped to focus the respondents on the domain under analysis.

Other journal ranking studies used a defined list of journals. In this study the survey contained an extensive journal list and the survey allowed faculty to add to the list. Therefore, the journal list emerged from the respondents rather than being predefined by the researcher. This should reduce framing bias (Judd, Smith and Kidder 1991) and allow the respondents to include the non-accounting journals that publish AIS papers (Christensen, Finger and Latham 2002).

Other journal ranking studies asked all respondents to rank every journal. The survey used in this study asked faculty to classify only the journals they were familiar with. This should reduce the number of uninformed ranking choices. In addition, the other studies used the magnitude method while this study employed a clearly defined list of quality grades. Graded responses may give more precise and reliable information about the subjects' perceptions (Judd, Smith and Kidder 1991).

Since the survey collected demographic data, the paper reports how different kinds of faculty responded to the ranking questions. Demographically the respondents were diverse with a wide variety of experience and background. For example, the paper reports the variation between respondents from AACSB versus Non-AACSB schools and highly published respondents versus respondents with a limited number of publications. In addition, the replies of respondents employed at doctorial granting universities were reported. 


\section{METHODS AND HYPOTHESES}

AIS professors were surveyed by mail. The sample was taken from members of the AAA IS section and AAA Artificial Intelligence and Emerging Technology (AI/ET) section. A survey was chosen over a citation study because this study is attempting to ascertain several perceptions of AIS faculty. This study not only ranks journals but also measures faculty familiarity with various journals. In addition, this study tests the difference between different types of faculty such as faculty from AACSB schools and non-AACSB schools. Finally, the study developed a list of journals that faculty deemed to be not appropriate for AIS research outlets. This depth of information could not be collected and examined with a citation study.

Journals listed in the survey were gleaned from the index of AIS journals included in Cabell's Directory of Publishing Opportunities in Accounting (Cabell and English, 2001-2002), Global Perspectives of IS Journals (Mylonopoulos and Theoharakis 2001), and the Brown and Huefner (1994) study. In addition, the survey respondents could add journals to the list. The original list started with 142 journals and 65 journals were added by the respondents, resulting in a total of 207 journals. The respondents scored 116 journals. Accordingly, the list of journals is more extensive when compared to other studies of this type. In addition, the journals were compared with the list produced in: Where Do AIS Researchers Publish? (Baldwin, Morris and Scheiner 2000) and all of the high frequency AIS journals were represented in the results of this survey. A comprehensive list of the journals ranked in this paper is in the appendix to this paper. At the bottom of the appendix are four notes that explain any changes in journal names. If a journal was ranked twice under its old name and new name, the scores were consolidated and the journal was listed in the paper under its new name.

Each survey was pre-numbered, included a cover letter explaining the purpose of the survey, and a business reply envelope which was return postage paid for US mailings. In the survey, respondents were asked to rate AIS journals on a scale which is defined below. In addition to journal classification, respondents were also asked a supply demographics information. For items one through four Brown and Huefner's (1994) journal ranking system was adopted with small modifications:

- Most Prestigious AIS Journals: These journals are widely recognized as the primary outlets for articles in AIS. Most of the leading articles in AIS appear in these journals. Publication in these journals is viewed as very prestigious and highly visible.

- Significant AIS Journals: These are respected as typically containing articles of good quality but are not as widely recognized as category 1 journals. Publication in these journals is viewed as a significant accomplishment.

- Creditable AIS Journals: These journals have some degree of recognition and contain work of varying quality. Publication in them is viewed as a contribution but not as significant as a publication in a category 2 journal.

- Insignificant AIS Journals: These journals have extremely little recognition or visibility and are not viewed as meaningful outlets for academic authors.

- Journals Not Appropriate for AIS Related Papers: These journals may or may not be prestigious. However, they are not appropriate outlets for AIS related research. These journals specialize in subjects such as financial, managerial, auditing, governmental, or tax and would rarely publish AIS papers.

Brown and Huefner's scale from their Contemporary Accounting Research article was used because it provides a reasonable approach to assigning ratings to journals and it passed the scrutiny of a rigorous journal. Furthermore, the Brown and Huefner scale distinguishes this study from other related studies. Individual faculty members were used to pretest the survey. The survey was distributed to five professors who examined and tested the survey for time, clarity, relevance and understandability. The survey was adjusted to incorporate several suggested improvements. The five faculty members clearly understood the Brown and Huefner scale.

In the results section, comparisons are made between the responses of faculty from AACSB accredited schools and non-AACSB accredited schools (see Tables 4, 5, 6, 7, 8 and 9). In addition, Table 10 compares the 
responses of faculty with three or less publications with the responses of faculty with four or more publications. To help explain the observed comparisons the following two null hypotheses were tested (Judd, Smith, and Kidder 1991):

Hypothesis 1: The journal ranking proportions (p) by faculty from AACSB accredited schools will be equal to the journal ranking proportions by faculty from non-AACSB schools $\left(H_{1}: p_{1}=p_{2}\right.$ or $\left.p_{1}-p_{2}=0\right)$.

Hypothesis 2: The journal ranking proportions (p) by faculty with three or less publications will be equal to the journal ranking proportions by faculty with four or more publications $\left(H_{2}: p_{1}=p_{2}\right.$ or $\left.p_{1}-p_{2}=0\right)$.

The equality of the proportions, where respondents classified journals into categories (prestigious, significant, creditable, etc...), were tested using the chi-square distribution $\left(X^{2}\right)$, (Keller and Warrack, 2003), (Kohler 2002). This statistical examination employed 2 -tailed, non-directional tests with $95 \%$ confidence $(\alpha=5 \%)$. The results are reported in the following section.

\section{RESULTS}

According to Alreck and Settle (1995), response rates for mail surveys are normally five to ten percent and response rates above 30 percent are rare. The usable response rate from this survey was $15.6 \%$. The response statistics are listed below:

- $\quad$ Population of AIS Faculty Indicating D (computer) or S (systems) Based on Hasselback (2004): 1,288

- $\quad$ Surveys Mailed: 936 (sample is $936 / 1,288=72.7 \%$ of population)

- $\quad$ Surveys Returned: 162

- Unusable Surveys: 16

- Usable Surveys: 146 (data set is $146 / 1,288=11.3 \%$ of population)

- $\quad$ Total Response Rate: $17.3 \%$

- $\quad$ Usable Response Rate: $15.6 \%$

A 15.6 percent usable response rate may raise question of non-response bias. However, the 146 usable surveys is the largest response to date from a survey concerning AIS professor perceptions of journal quality. In addition, the respondents represent the diversity of the population in many respects. For example, AACSB accredited schools and qualified faculty were well represented. Descriptive statistics of schools (Table 2) and respondents (Table 3) are displayed below:

Table 2 shows that 65.8 percent of the respondents were from AACSB accredited schools and 79.5 percent of the respondents were from AACSB accredited schools or schools that are candidates for accreditation. Faculty at AACSB accredited and AACSB candidate schools may be more desirable respondents because of their increased focus on research and publishing. The emphasis on publishing that must be demonstrated for faculty to be designated as academically qualified should make respondents from AACSB accredited schools very knowledge about the journals in their field.

Approximately 84 percent of the respondents were from the United States. Two factors may have caused skewness in geography. First, the original sample included approximately 22 percent foreign professors. Secondly, due to budget constraints, return postage was not included for foreign survey participants. Therefore anyone responding from outside the United States was required to pay postage to return the survey. The fact that the majority of the respondents were from the United States may reduce the usefulness of the results for understanding the perceptions of AIS journal quality by international faculty. 
Table 2: University Profiles Where Respondents Work

\begin{tabular}{|l|c|}
\hline AACSB Status: & Percent \\
\hline Not AACSB Accredited & 20.5 \\
\hline Candidate for Accreditation & 13.7 \\
\hline AACSB Accredited & 65.8 \\
\hline Total & 100.0 \\
\hline & \\
\hline Type of College: & Percent \\
\hline Private College & 30.1 \\
\hline Public College & 69.9 \\
\hline Total & 100.0 \\
\hline & \\
\hline College Location: & Percent \\
\hline No Response & 1.4 \\
\hline Canada & 1.4 \\
\hline South America & .7 \\
\hline Asia & 8.2 \\
\hline Europe & 2.7 \\
\hline Australia & 1.4 \\
\hline USA & 84.2 \\
\hline Total & 100.0 \\
\hline
\end{tabular}

\begin{tabular}{|l|c|}
\hline $\begin{array}{l}\text { Number of Full Time Faculty in the } \\
\text { Business Division: }\end{array}$ & Percent \\
\hline No Response & 1.5 \\
\hline 0 to10 & 4.1 \\
\hline 11 to 20 & 6.8 \\
\hline 21 to 30 & 10.3 \\
\hline 31 to 40 & 13.0 \\
\hline 41 to 50 & 8.2 \\
\hline 51 to 60 & 7.5 \\
\hline 61 to 70 & 9.6 \\
\hline Greater than 70 & 39.0 \\
\hline Total & 100.0 \\
\hline & \\
\hline Business Related Degrees Awarded: & Percent \\
\hline Associate & 2.0 \\
\hline Bachelor & 31.0 \\
\hline Master of Science & 19.5 \\
\hline MBA & 27.1 \\
\hline Doctorate & 16.7 \\
\hline Other & 3.7 \\
\hline Total & 100.0 \\
\hline
\end{tabular}

Table 3: Respondent Profiles

\begin{tabular}{|l|c|}
\hline Faculty Rank: & Percent \\
\hline Adjunct & 1.4 \\
\hline Lecturer or Instructor & 6.2 \\
\hline Assistant & 35.6 \\
\hline Associate & 27.4 \\
\hline Professor & 17.1 \\
\hline Distinguished & 3.4 \\
\hline Emeritus & .7 \\
\hline Student & 6.8 \\
\hline No Response & 1.4 \\
\hline Total & 100.0 \\
\hline & \\
\hline Tenure Status: & Percent \\
\hline Non-tenured & 55.5 \\
\hline Tenured & 41.8 \\
\hline No Response & 2.7 \\
\hline Total & 100.0 \\
\hline & \\
\hline Highest Degree Earned: & Percent \\
\hline Associate & .7 \\
\hline Bachelor & .7 \\
\hline Master & 15.8 \\
\hline JD or LLM & 0 \\
\hline ED & .7 \\
\hline PhD or DBA & 78.8 \\
\hline No Response & 3.3 \\
\hline Total & \\
\hline
\end{tabular}

\begin{tabular}{|c|c|c|}
\hline $\begin{array}{l}\text { Refereed Journal } \\
\text { Publications: }\end{array}$ & Percent & $\begin{array}{c}\text { Cumulative } \\
\text { Percent }\end{array}$ \\
\hline 0 & 21.9 & 21.9 \\
\hline 1 to 3 & 22.7 & 44.6 \\
\hline 4 to 6 & 10.3 & 54.9 \\
\hline 7 to 9 & 6.9 & 61.8 \\
\hline 10 to 12 & 11.7 & 73.5 \\
\hline 13 to 15 & 3.5 & 77.0 \\
\hline 16 to 18 & .7 & 77.7 \\
\hline 19 to 21 & 4.8 & 82.5 \\
\hline 22 to 24 & 1.4 & 83.9 \\
\hline 25 to 27 & 3.4 & 87.3 \\
\hline 28 to 30 & 1.4 & 88.7 \\
\hline Greater Than 30 & 6.2 & 94.9 \\
\hline No Response & 5.1 & 100.0 \\
\hline Total & 100.0 & \\
\hline & & \\
\hline $\begin{array}{c}\text { Years of Full Time } \\
\text { Teaching: }\end{array}$ & Percent & $\begin{array}{c}\text { Cumulative } \\
\text { Percent }\end{array}$ \\
\hline 0 to 5 & 31.5 & 31.5 \\
\hline 6 to 10 & 18.5 & 50.0 \\
\hline 11 to 15 & 16.4 & 66.4 \\
\hline 16 to 20 & 11.6 & 78.0 \\
\hline 21 to 25 & 7.5 & 85.5 \\
\hline Greater than 25 & 11.0 & 96.5 \\
\hline No Response & 3.5 & 100.0 \\
\hline Total & 100.0 & \\
\hline
\end{tabular}


As seen in Table 3, 78.8 percent of the respondents have earned a Ph. D. or DBA, which may further contribute to the credibility of this sample. Over 41 percent of the sample held a tenured position and 63 percent of the sample was either an Assistant or Associate Professor. Slightly more than 17 percent of the faculty held the rank of Full Professor. The respondents to the survey were experienced faculty. Some 65 percent had over five years of full time teaching experience.

Next, journal familiarity was examined through the use of two measures. First, respondents were asked: What three AIS related journals do you read and are the most familiar with? Secondly, respondents were asked: What are the three most prestigious journals where you have published AIS related papers?

Table 4: Journals that Respondents Read by Percent of Respondents

\begin{tabular}{|c|c|c|c|c|c|c|}
\hline Rank & Journal and Abbreviation & Overall & AACSB & $\begin{array}{c}\text { Non- } \\
\text { AACSB }\end{array}$ & Difference & $\begin{array}{c}\text { Chi-square } \\
\text { Test }\end{array}$ \\
\hline 1 & $\begin{array}{l}\begin{array}{l}\text { Journal of Information } \\
\text { (JIS) }\end{array} \\
\end{array}$ & 74.2 & 78.0 & 67.4 & 10.6 & .182 \\
\hline 2 & $\begin{array}{l}\text { Intl. J. of Accounting Information } \\
\text { Systems (IJAIS) }\end{array}$ & 26.6 & 26.8 & 26.1 & 0.7 & .888 \\
\hline 3 & MIS Quarterly (MISQ) & 19.5 & 19.5 & 19.6 & -0.1 & .976 \\
\hline 4 & Journal of Accountancy (JA) & 11.7 & 11.0 & 13.0 & -2.0 & .658 \\
\hline 5 & $\begin{array}{l}\text { Review of Business Information } \\
\text { Systems (RBIS) }\end{array}$ & 11.0 & 13.4 & 6.5 & 6.9 & .166 \\
\hline 6 & Accounting Review (AR) & 10.9 & 7.3 & 17.4 & -10.1 & $.049^{1}$ \\
\hline 7 & Accounting Horizons $(\mathrm{AH})$ & 7.8 & 6.1 & 10.9 & -4.8 & .415 \\
\hline 7 & $\begin{array}{l}\text { Intl. J. of Intelligent Sys. in Acc., } \\
\text { Fin. \& Mgt. (IJIS) }\end{array}$ & 7.8 & 6.1 & 10.9 & -4.8 & .415 \\
\hline 9 & Management Science (MS) & 7.0 & 8.5 & 4.3 & 4.2 & .325 \\
\hline 10 & Journal of MIS (JMIS) & 5.5 & 7.3 & 2.2 & 5.1 & .182 \\
\hline 11 & Decision Sciences (DS) & 3.9 & 2.4 & 6.5 & -4.1 & .217 \\
\hline 12 & $\begin{array}{l}\text { Auditing: Journal of Practice and } \\
\text { Theory (AUD) }\end{array}$ & 3.9 & 1.2 & 8.7 & -7.5 & $.028^{1}$ \\
\hline 12 & $\begin{array}{l}\text { Issues in Accounting Education } \\
\text { (IAE) }\end{array}$ & 3.9 & 1.2 & 8.7 & -7.5 & $.028^{1}$ \\
\hline 12 & $\begin{array}{l}\text { Information Systems Management } \\
\text { (ISM) }\end{array}$ & 3.9 & 1.2 & 8.7 & -7.5 & $.028^{1}$ \\
\hline 12 & Internal Auditor (IA) & 3.9 & 3.7 & 4.3 & -0.6 & .962 \\
\hline 12 & IS Research (ISR) & 3.9 & 6.0 & 0.0 & 6.0 & .071 \\
\hline 12 & Strategic Finance Magazine (SFM) & 3.9 & 4.9 & 2.2 & 2.7 & .354 \\
\hline 12 & $\begin{array}{lll}\text { Information } & \text { Systems } & \text { Control } \\
\text { Journal (ISC) } & & \\
\end{array}$ & 3.9 & 4.9 & 2.2 & 2.7 & .354 \\
\hline
\end{tabular}

${ }^{1}$ Reject the null hypothesis H1

Table 4 shows the journals that respondents were most familiar with. The responses from AACSB schools are compared to responses from non-AACSB schools and the differences are displayed. The journal rankings that resulted from the survey feedback allowed for tied scores. The Journal of Information Systems (JIS) was the most familiar journal with 74.2 percent of the respondents indicating familiarity. Other journals with high familiarity were the International Journal of AIS (IJAIS), MIS Quarterly (MISQ), Journal of Accountancy (JA), Accounting Review (AR), and Review of Business Information Systems (RBIS). It is interesting to note that respondents from AACSB schools did not read the Accounting Review as much as respondents from non-AACSB schools. 
Table 5: Journals Where Respondents Have Published by Percent of Respondents

\begin{tabular}{|c|l|c|c|c|c|c|}
\hline Rank & Journal and Abbreviation & Overall & AACSB & $\begin{array}{c}\text { Non- } \\
\text { AACSB }\end{array}$ & $\begin{array}{c}\text { Difference } \\
\text { Chi-square } \\
\text { Test }\end{array}$ \\
\hline 1 & $\begin{array}{l}\text { Journal of Information Systems } \\
\text { JIS) }\end{array}$ & 26.0 & 28.3 & 17.6 & 10.7 & .178 \\
\hline 2 & $\begin{array}{l}\text { Review of Business Information } \\
\text { Systems (RBIS) }\end{array}$ & 20.8 & 18.3 & 29.4 & -11.1 & .123 \\
\hline 3 & International Journal of AIS (IJAIS) & 19.5 & 16.7 & 29.4 & -12.7 & .062 \\
\hline 4 & Journal of Accountancy (JA) & 10.4 & 11.7 & 5.9 & 5.8 & .288 \\
\hline 5 & CPA Journal (CPAJ) & 7.8 & 8.3 & 5.9 & 2.4 & .612 \\
\hline 5 & Accounting Review (AR) & 7.8 & 10.0 & 0.0 & 10.0 & $.018^{1}$ \\
\hline 7 & $\begin{array}{l}\text { Behavioral Research in Accounting } \\
\text { BRA) }\end{array}$ & 6.5 & 8.3 & 0.0 & $.036^{1}$ \\
\hline 7 & $\begin{array}{l}\text { Auditing: Journal of Practice and } \\
\text { Theory (AUD) }\end{array}$ & 6.5 & 8.3 & 0.0 & 8.3 & $.036^{1}$ \\
\hline 9 & Decision Sciences (DS) & 5.2 & 6.7 & 0.0 & 6.7 & .071 \\
\hline 9 & $\begin{array}{l}\text { Intl. J. of Intelligent Systems in } \\
\text { Acc., Finance \& Mgt. (IJIS) }\end{array}$ & 5.2 & 6.7 & 0.0 & 6.7 & .071 \\
\hline 9 & Management Accounting (MA) & 5.2 & 6.7 & 0.0 & 6.7 & .071 \\
\hline 9 & MIS Quarterly (MISQ) & 5.2 & 6.7 & 0.0 & 6.7 & .071 \\
\hline 9 & Management Science (MS) & 5.2 & 5.0 & 5.9 & -0.9 & .842 \\
\hline 14 & Strategic Finance Magazine (SFM) & 3.9 & 5.0 & 0.0 & 5.0 & .101 \\
\hline 14 & $\begin{array}{l}\text { Accounting, Organizations and } \\
\text { Society (AOS) }\end{array}$ & 3.9 & 5.0 & 0.0 & 5.0 & .101 \\
\hline 14 & $\begin{array}{l}\text { Communications of the ACM } \\
\text { CACM) }\end{array}$ & 3.9 & 3.3 & 5.9 & -2.6 & .406 \\
\hline
\end{tabular}

${ }^{1}$ Reject the null hypothesis H1

Table 5 summarizes the AIS journals where the respondents have published. It must be noted that there is no adjustment for co-authorship. Thus, if two separate respondents each indicated that they published "an article" in a particular journal, this study double counted the journal. Once again, the responses from AACSB schools are compared to responses from non-AACSB schools and the differences are displayed. As expected, most of the journals where faculty published are also the most read AIS journals. It is interesting to note that several journals the survey respondents published in were not listed as the most read. Those journals include but are not limited to Behavioral Research in Accounting, The CPA Journal, Management Accounting, Abacus and Accounting Organizations and Society.

At this point, journal rankings will be examined. The following three tables show a list of journals rated as prestigious, significant and creditable. These tables display the journals in each category and the percentage of respondents that ranked the journal in that particular category.

The Journal of Information Systems (JIS) was ranked most prestigious by 67.7 percent of the respondents. The second place journal in the most prestigious category was MIS Quarterly (MISQ) which generated favorable responses from 47.2 percent of the faculty. A review of Table 6 also discloses that faculty from AACSB accredited schools ranked MIS Quarterly (MISQ) and Decision Sciences significantly higher than faculty from non-AACSB schools. In contrast, faculty from non-AACSB schools favored the International Journal of Intelligent Systems in Accounting, Finance and Management (IJIS) and the Journal of Accountancy (JA) in the prestigious category. 
Table 6: Journals in the Most Prestigious Category Ranked by Percent of Respondents

\begin{tabular}{|c|c|c|c|c|c|c|}
\hline Rank & Journal Name and Abbreviation & Overall & AACSB & $\begin{array}{c}\text { Non- } \\
\text { AASCB }\end{array}$ & Difference & $\begin{array}{c}\text { Chi-square } \\
\text { Test }\end{array}$ \\
\hline 1 & Journal of Info. Systems (JIS) & 67.7 & 67.1 & 69.0 & -1.9 & .682 \\
\hline 2 & MIS Quarterly (MISQ) & 47.2 & 52.9 & 35.7 & 17.2 & $.049^{1}$ \\
\hline 3 & International Journal of AIS (IJAIS) & 26.8 & 23.5 & 33.3 & -9.8 & .197 \\
\hline 4 & Decision Sciences (DS) & 22.8 & 28.2 & 11.9 & 16.3 & $.027^{1}$ \\
\hline 5 & Accounting Review (AR) & 22.0 & 22.4 & 21.4 & 1.0 & .900 \\
\hline 6 & Journal of MIS (JMIS) & 19.7 & 21.2 & 16.7 & 4.5 & .481 \\
\hline 7 & Acc., Orgs. and Society (AOS) & 18.1 & 17.6 & 19.0 & -1.4 & .735 \\
\hline 8 & Management Science (MS) & 15.7 & 18.8 & 9.5 & 9.3 & .168 \\
\hline 9 & IS Research (ISR) & 15.0 & 16.5 & 11.9 & 4.6 & .454 \\
\hline 10 & $\begin{array}{l}\text { Communications of the ACM } \\
(\mathrm{CACM})\end{array}$ & 13.4 & 12.9 & 14.3 & -1.4 & .798 \\
\hline 11 & $\begin{array}{l}\text { Auditing: J. of Practice and Theory } \\
\text { (AUD) }\end{array}$ & 8.7 & 9.4 & 7.1 & 2.3 & .782 \\
\hline 11 & J. of Accounting Research (JAR) & 8.7 & 9.4 & 7.1 & 2.3 & .782 \\
\hline 13 & Behavioral Research in Acc. (BRA) & 7.1 & 8.2 & 4.8 & 3.4 & .325 \\
\hline 13 & $\begin{array}{l}\text { Intl. J. of Intelligent Sys. in Acc., Fin. } \\
\text { \& Mgt. (IJIS) }\end{array}$ & 7.1 & 3.5 & 14.3 & -10.8 & $.014^{1}$ \\
\hline 15 & Journal of Accountancy (JA) & 6.3 & 3.5 & 11.9 & -8.4 & $.034^{1}$ \\
\hline 15 & IEEE Trans. (various) (IEEET) & 6.3 & 5.9 & 7.1 & -1.2 & .691 \\
\hline 15 & Information Systems Journal (ISJ) & 6.3 & 5.9 & 7.1 & -1.2 & .691 \\
\hline 18 & Harvard Business Review (HBR) & 5.5 & 5.9 & 4.8 & 1.1 & .571 \\
\hline 18 & Journal of the ACM (JACM) & 5.5 & 5.9 & 4.8 & 1.1 & .571 \\
\hline 18 & $\begin{array}{l}\text { Review of Business } \text { Information } \\
\text { Systems (RBIS) }\end{array}$ & 5.5 & 4.7 & 7.1 & -2.4 & .506 \\
\hline
\end{tabular}

${ }^{1}$ Reject the null hypothesis H1

Table 7: Journals in the Significant Category Ranked by Percent of Respondents

\begin{tabular}{|c|c|c|c|c|c|c|}
\hline Rank & Journal Name and Abbreviation & Overall & AACSB & $\begin{array}{c}\text { Non- } \\
\text { AACSB }\end{array}$ & Difference & $\begin{array}{c}\text { Chi-square } \\
\text { Test }\end{array}$ \\
\hline 1 & International Journal of AIS (IJAIS) & 21.2 & 24.7 & 13.9 & 10.8 & .123 \\
\hline 2 & Journal of Info. Systems (JIS) & 17.7 & 19.5 & 13.9 & 5.6 & .470 \\
\hline 3 & Information Systems Journal (ISJ) & 15.9 & 13.0 & 22.2 & -9.2 & .135 \\
\hline 4 & IS Control Journal (ISC) & 15.1 & 13.0 & 19.4 & -6.4 & .229 \\
\hline 5 & Journal of Accountancy (JA) & 15.0 & 18.2 & 8.3 & 9.9 & .113 \\
\hline 5 & $\begin{array}{l}\text { Auditing: J. of Practice \& Theory } \\
\text { (AUD) }\end{array}$ & 15.0 & 18.2 & 8.3 & 9.9 & .113 \\
\hline 7 & $\begin{array}{l}\text { Intl. J. of Intelligent Systems in Acc., } \\
\text { Fin., \& Mgt. (IJIS) }\end{array}$ & 13.3 & 16.9 & 5.6 & 11.3 & .069 \\
\hline 7 & Acc., Orgs. \& Society (AOS) & 13.3 & 14.3 & 11.1 & 3.2 & .667 \\
\hline 9 & Decision Sciences (DS) & 11.5 & 14.3 & 5.6 & 8.7 & .125 \\
\hline 9 & Accounting Horizons $(\mathrm{AH})$ & 11.5 & 7.8 & 19.4 & -11.6 & $.023^{1}$ \\
\hline 9 & Behavioral Research in Acc. (BRA) & 11.5 & 10.4 & 13.9 & -3.5 & .522 \\
\hline 9 & Review of Bus. Info. Sys. (RBIS) & 11.5 & 11.7 & 11.1 & 0.6 & .923 \\
\hline 13 & Issues in Acc. Education (IAE) & 10.6 & 9.1 & 13.9 & -4.8 & .396 \\
\hline 13 & Decisions Support Systems (DSS) & 10.6 & 11.7 & 8.3 & 3.4 & .514 \\
\hline 15 & IEEE Trans. (various) (IEEET) & 9.7 & 14.3 & 0.0 & 14.3 & $.005^{1}$ \\
\hline 15 & IS Research (ISR) & 9.7 & 11.7 & 5.6 & 6.1 & .288 \\
\hline 15 & Information and Organization (IO) & 9.7 & 10.4 & 8.3 & 2.1 & .638 \\
\hline 18 & Information Systems Mgt. (ISM) & 8.8 & 9.1 & 8.3 & 0.8 & .782 \\
\hline 18 & Information and Management (IM) & 8.8 & 7.8 & 11.1 & -3.3 & .343 \\
\hline 18 & Com. of the ACM (CACM) & 8.8 & 11.7 & 2.8 & 8.9 & $.048^{1}$ \\
\hline 21 & MIS Quarterly (MISQ) & 8.0 & 5.2 & 13.9 & -8.7 & .066 \\
\hline 22 & Journal of MIS (JMIS) & 8.0 & 11.7 & 0.0 & 11.7 & $.013^{1}$ \\
\hline
\end{tabular}

${ }^{1}$ Reject the null hypothesis H1 
In the Significant category, the International Journal of Accounting Information Systems (IJAIS) received over 21 percent of the votes. Table 7 also reveals that faculty from AACSB accredited schools ranked IEEE Transactions (IEEET), Communications of the ACM (CACM) and the Journal of MIS (JMIS) significantly higher than faculty from non-AACSB schools. Alternatively, faculty from non-AACSB schools favored Accounting Horizons (AH) in the significant category. JIS also had 17.7 percent of the respondents vote for it in the significant category.

Table 8: Journals in the Creditable Category Ranked by Percent of Respondents

\begin{tabular}{|c|l|c|c|c|c|c|}
\hline Rank & Journal Name and Abbreviation & Overall & AACSB & $\begin{array}{c}\text { Non- } \\
\text { AACSB }\end{array}$ & $\begin{array}{c}\text { Difference } \\
\text { Chi-square } \\
\text { Test }\end{array}$ \\
\hline 1 & IS Control Journal (ISC) & 22.4 & 25.8 & 14.3 & 11.5 & .095 \\
\hline 2 & Review of Bus. Info. Sys. (RBIS) & 18.1 & 19.7 & 14.3 & 5.4 & .385 \\
\hline 3 & CPA Journal (CPAJ) & 17.0 & 21.2 & 7.1 & 14.1 & $.047^{1}$ \\
\hline 4 & Journal of Accountancy (JA) & 14.9 & 16.7 & 10.7 & 6.0 & .276 \\
\hline 5 & Internal Auditor (IA) & 13.8 & 18.2 & 3.6 & 14.6 & $.019^{1}$ \\
\hline 6 & Accounting Horizons (AH) & 12.8 & 15.2 & 7.1 & 8.1 & .194 \\
\hline 7 & Communications of the AIS (CAIS) & 10.6 & 10.6 & 10.7 & -0.1 & .937 \\
\hline 7 & Strategic Finance Magazine (SFM) & 10.6 & 12.1 & 7.1 & 5.0 & .409 \\
\hline 9 & International Journal of AIS (IJAIS) & 9.6 & 12.1 & 3.6 & 8.5 & .098 \\
\hline 9 & Issues in Acc. Education (IAE) & 9.6 & 6.1 & 17.9 & -11.8 & $.026^{1}$ \\
\hline 9 & J. of Acc. and Computers (JAC) & 9.6 & 9.1 & 10.7 & -1.6 & .903 \\
\hline 12 & Management Accounting (MA) & 8.5 & 7.6 & 10.7 & -3.1 & .572 \\
\hline 12 & Decision Sciences (DS) & 8.5 & 6.1 & 14.3 & -8.2 & .119 \\
\hline 14 & Journal of MIS (JMIS) & 7.4 & 6.1 & 10.7 & -4.6 & .415 \\
\hline 14 & Accounting Educator's J. (AEJ) & 7.4 & 6.1 & 10.7 & -4.6 & .415 \\
\hline 16 & Information Systems Journal (ISJ) & 6.4 & 9.1 & 0.0 & 9.1 & $.025^{1}$ \\
\hline 16 & Intl. J. of Intel. Sys. in Acc., Fin., \& & 6.4 & 7.6 & 3.6 & 4.0 & .433 \\
\hline 16 & Mgt. (IJIS) & & & & & $.025^{1}$ \\
\hline 16 & European Journal of IS (EJIS) & 6.4 & 6.1 & 7.1 & .1 & .691 \\
\hline
\end{tabular}

${ }^{1}$ Reject the null hypothesis H1

In the creditable category, the IS Control Journal (ISC) ranked first with 22.4 percent and the Review of Business Information Systems (RBIS) ranked second with 18.1 percent of the votes from the respondents. Notable entries in the survey were the Journal of Accountancy (JA) and The CPA Journal (CPAJ) which received 14.9 percent and 17 percent, respectively, in the creditable category.

The results of this study are surprising. In the majority of other surveys the Accounting Review (AR) and the Journal of Accounting Research $(J A R)$ are the top two journals. In this AIS survey the Journal of Information Systems ranked first and it was supported equally by respondents from both AASCB and Non-AACSB schools.

The difference in rankings may be due to the fact that this survey sample included only professors with interests in AIS and AI/ET. As displayed in Table 9, the respondents did not consider AR and JAR to be appropriate AIS outlets. This is verified by the findings of Stone (2002) who reported that the top five accounting journals ( $A R$, $A O S, C A R, J A E, J A R$ ) only published six AIS papers from 1989 to 1998 . It is also worth noting that faculty from AACSB schools disagreed with faculty from non-AACSB schools on eight of the top ten not appropriate journals. 
Table 9: Journals in the Not Appropriate Category by Percent of Respondents

\begin{tabular}{|c|c|c|c|c|c|c|}
\hline Rank & Journal Name and Abbreviation & Overall & AACSB & $\begin{array}{c}\text { Non- } \\
\text { AACSB }\end{array}$ & Difference & $\begin{array}{c}\text { Chi-square } \\
\text { Test }\end{array}$ \\
\hline 1 & Accounting Review (AR) & 48.6 & 48.9 & 47.8 & 1.1 & .912 \\
\hline 2 & Journal of Accounting Research (JAR) & 47.1 & 55.3 & 30.4 & 24.9 & $.004^{1}$ \\
\hline 3 & $\begin{array}{l}\text { Journal of Accounting and Economics } \\
\text { (JAE) }\end{array}$ & 41.4 & 44.7 & 34.8 & 9.9 & .209 \\
\hline 4 & $\begin{array}{l}\text { Contemporary Accounting Research } \\
\text { (CAR) }\end{array}$ & 38.6 & 48.9 & 17.4 & 31.5 & $.001^{1}$ \\
\hline 5 & $\begin{array}{l}\text { Journal of Accounting, Auditing \& } \\
\text { Finance (JAAF) }\end{array}$ & 24.3 & 31.9 & 8.7 & 23.2 & $.001^{1}$ \\
\hline 6 & Harvard Business Review (HBR) & 22.9 & 19.1 & 30.4 & -11.3 & .123 \\
\hline 7 & $\begin{array}{l}\text { Journal of the American } \\
\text { Association (JATA) }\end{array}$ & 20.0 & 27.7 & 4.3 & 23.4 & $.001^{1}$ \\
\hline 7 & Advances in Taxation (AT) & 20.0 & 29.8 & 0.0 & 29.8 & $.001^{1}$ \\
\hline 9 & Journal of Taxation (JT) & 18.6 & 25.5 & 4.3 & 21.2 & $.002^{1}$ \\
\hline 10 & Accounting Horizons (AH) & 17.1 & 12.8 & 26.1 & -13.3 & $.040^{1}$ \\
\hline 10 & Tax Advisor (TA) & 17.1 & 23.4 & 4.3 & 19.1 & $.003^{1}$ \\
\hline 12 & $\begin{array}{l}\text { J. of Management Accounting } \\
\text { Research (JMAR) }\end{array}$ & 15.7 & 12.8 & 21.7 & -8.9 & .135 \\
\hline 12 & $\begin{array}{l}\begin{array}{l}\text { Journal of Accounting } \\
\text { (JAL) }\end{array} \\
\end{array}$ & 15.7 & 19.1 & 8.7 & 10.4 & .945 \\
\hline 12 & $\begin{array}{l}\text { Accounting, Organizations \& Society } \\
\text { (AOS) }\end{array}$ & 15.7 & 17.0 & 13.0 & 4.0 & .675 \\
\hline 15 & $\begin{array}{l}\text { Auditing: Journal of Practice and } \\
\text { Theory (AUD) }\end{array}$ & 14.3 & 12.8 & 17.4 & -4.6 & .369 \\
\hline 15 & $\begin{array}{l}\text { Journal of Accounting and Public } \\
\text { Policy (JAPP) }\end{array}$ & 14.3 & 17.0 & 8.7 & 8.3 & .148 \\
\hline 15 & Abacus (AB) & 14.3 & 12.8 & 17.4 & -4.6 & .369 \\
\hline 18 & $\begin{array}{l}\text { Critical Perspectives on Accounting } \\
\text { (CPA) }\end{array}$ & 12.9 & 10.1 & 16.4 & -6.3 & .123 \\
\hline 18 & Tax Notes (TN) & 12.9 & 17.0 & 4.3 & 12.7 & $.027^{1}$ \\
\hline 20 & $\begin{array}{l}\text { Academy of Management Review } \\
\text { (AMR) }\end{array}$ & 11.4 & 14.9 & 4.3 & 10.6 & .052 \\
\hline 20 & Tax Law Review (TLR) & 11.4 & 17.0 & 0.0 & 17.0 & $.002^{1}$ \\
\hline 20 & Accounting Historians Journal (AHJ) & 11.4 & 14.9 & 4.3 & 10.6 & .052 \\
\hline 20 & Taxes - The Tax magazine (TAXES) & 11.4 & 14.9 & 4.3 & 10.6 & .052 \\
\hline
\end{tabular}

${ }^{1}$ Reject the null hypothesis $\mathrm{H} 1$

Next, a composite ranking of the journals was calculated. Two methods were employed. First, the frequencies of a journal being classified as prestigious, significant and creditable were totaled and presented in Table 10. Secondly, a composite score based on a weighting formula was calculated and presented in Table 11. Journal abbreviations are defined in the Appendix. 
Table 10: AIS Journals in the Prestigious, Significant or Creditable Categories Excluding the Top 10 Inappropriate Journals by Percent of Respondents

\begin{tabular}{|c|c|c|c|c|c|c|}
\hline Rank & $\begin{array}{c}\text { Journal } \\
\text { Abbreviation }\end{array}$ & Overall & $\begin{array}{c}3 \text { or Less } \\
\text { Publications }\end{array}$ & $\begin{array}{c}4 \text { or More } \\
\text { Publications }\end{array}$ & Difference & $\begin{array}{c}\text { Chi-square } \\
\text { Test } \\
\end{array}$ \\
\hline 1 & JIS & 88.0 & 84.5 & 91.0 & -6.5 & .207 \\
\hline 2 & MISQ & 54.4 & 55.2 & 53.7 & 1.5 & .782 \\
\hline 3 & IJAIS & 52.8 & 48.3 & 56.7 & -8.4 & .274 \\
\hline 4 & DS & 39.2 & 36.2 & 41.8 & -5.6 & .535 \\
\hline 5 & ISC & 34.4 & 20.7 & 46.3 & -25.6 & $.004^{1}$ \\
\hline 6 & $\mathrm{AOS}$ & 32.0 & 32.8 & 31.3 & 1.5 & .852 \\
\hline 7 & JMIS & 31.2 & 36.2 & 26.9 & 9.3 & .207 \\
\hline 8 & JA & 30.4 & 36.2 & 25.8 & 10.4 & .153 \\
\hline 9 & RBIS & 29.6 & 24.1 & 34.3 & -10.2 & .193 \\
\hline 10 & ISR & 26.4 & 27.6 & 25.4 & 2.2 & .811 \\
\hline 11 & ISJ & 25.6 & 22.4 & 28.4 & -6.0 & .467 \\
\hline 12 & IJIS & 24.0 & 17.2 & 29.9 & -12.7 & .074 \\
\hline 13 & CACM & 23.2 & 27.6 & 19.4 & 8.2 & .259 \\
\hline 14 & AUD & 22.4 & 15.5 & 28.4 & -12.9 & .062 \\
\hline 15 & IAE & 20.0 & 20.7 & 19.4 & 1.3 & .970 \\
\hline 15 & BRA & 20.0 & 27.6 & 13.4 & 14.2 & $.034^{1}$ \\
\hline 17 & CPAJ & 18.4 & 17.2 & 19.4 & -2.2 & .662 \\
\hline 18 & DSS & 17.6 & 19.0 & 16.4 & 2.6 & .701 \\
\hline 18 & IA & 17.6 & 12.1 & 22.4 & -10.3 & .120 \\
\hline 20 & $\mathrm{IO}$ & 16.8 & 13.8 & 19.4 & -5.6 & .346 \\
\hline 21 & IEEET & 16.0 & 13.8 & 17.9 & -4.1 & .571 \\
\hline 22 & CAIS & 15.2 & 10.3 & 19.4 & -9.1 & .139 \\
\hline 22 & MS & 15.2 & 8.6 & 20.9 & -12.3 & .053 \\
\hline 24 & IM & 14.4 & 10.3 & 17.9 & -7.6 & .265 \\
\hline 24 & ISM & 14.4 & 19.0 & 10.4 & 8.6 & .134 \\
\hline 26 & JACM & 13.6 & 5.2 & 20.9 & -15.7 & $.004^{1}$ \\
\hline 26 & IEEEC & 13.6 & 8.6 & 17.9 & -9.3 & .160 \\
\hline 28 & JAC & 12.0 & 6.9 & 16.4 & -9.5 & .064 \\
\hline 28 & EJIS & 12.0 & 10.3 & 13.4 & -3.1 & .608 \\
\hline 28 & AABR & 12.0 & 13.8 & 10.4 & 3.4 & .457 \\
\hline 31 & SFM & 11.2 & 8.6 & 10.4 & -1.8 & .895 \\
\hline 31 & JAED & 11.2 & 6.9 & 14.9 & -8.0 & .096 \\
\hline 31 & JSIS & 11.2 & 6.9 & 14.9 & -8.0 & .096 \\
\hline 34 & IJEC & 10.4 & 5.2 & 14.9 & -9.7 & $.044^{1}$ \\
\hline
\end{tabular}

${ }^{1}$ Reject the null hypothesis $\mathrm{H} 2$

Table 10 consolidates the unadjusted frequencies from Tables 6, 7, and 8 . In addition, it excludes the top ten journals rated not appropriate for AIS research from Table 9. Table 10 also reports rankings from respondents based on their publication record. Overall the respondents ranked the Journal of Information of Systems (JIS) as the most prestigious, significant, and creditable journal. MIS Quarterly (MISQ) was a distant second, closely ranked with the International Journal of Accounting Information Systems (IJAIS).

Next, a composite score was calculated based on a weighted formula. Journals were ranked by the respondents in four categories: Most Prestigious, Significant, Creditable and Insignificant. Weights were assigned to three of the categories as follows:

- $\quad$ Most Prestigious $=4$

- $\quad$ Significant $=3$

- $\quad$ Creditable $=2$ 
To score a journal, a proportion of the number of times a journal was ranked in a specific category to the total number of respondents in that category, was multiplied by the weight. The result for each category for each journal was summed to arrive at a total score. Formula 1 was used to rank the 75 journals that appear in Table 11:

$\sum_{n=3}^{n=1}(i / r) w$

Where:

$\mathrm{i}=$ number of incidents of journal ranking in the specific category

$\mathrm{r}=$ number of respondents in the specific category

$\mathrm{w}=$ weight assigned to the specific category

$\mathrm{n}=$ categories 1 through 3

Range $=0$ to 9

\begin{tabular}{|c|c|c|}
\hline \multicolumn{1}{c}{} & Table 11: \\
\hline Rank & Journal & Score \\
\hline 1 & JIS & 3.367 \\
\hline 2 & MISQ & 2.150 \\
\hline 3 & IJAIS & 1.900 \\
\hline 4 & DS & 1.429 \\
\hline 5 & AOS & 1.186 \\
\hline 6 & JMIS & 1.175 \\
\hline 7 & ISC & 1.087 \\
\hline 8 & AR & 1.084 \\
\hline 9 & JA & 1.001 \\
\hline 10 & ISR & 0.976 \\
\hline 11 & RBIS & 0.927 \\
\hline 12 & CACM & 0.865 \\
\hline 13 & ISJ & 0.858 \\
\hline 14 & IJIS & 0.809 \\
\hline 15 & AUD & 0.803 \\
\hline 16 & AH & 0.789 \\
\hline 17 & BRA & 0.714 \\
\hline 18 & MS & 0.656 \\
\hline 19 & IAE & 0.636 \\
\hline 20 & DSS & 0.593 \\
\hline 21 & IO & 0.587 \\
\hline 21 & IEEET & 0.587 \\
\hline 23 & CPAJ & 0.531 \\
\hline 24 & IA & 0.520 \\
\hline 25 & JACM & 0.497 \\
\hline
\end{tabular}

\begin{tabular}{|c|c|c|}
\hline Rank & Journal & Score \\
\hline 26 & ISM & 0.477 \\
\hline 27 & CAIS & 0.471 \\
\hline 28 & IM & 0.466 \\
\hline 29 & IEEEC & 0.450 \\
\hline 30 & JAR & 0.442 \\
\hline 31 & HBR & 0.438 \\
\hline 32 & AABR & 0.397 \\
\hline 33 & EJIS & 0.376 \\
\hline 34 & JMAR & 0.370 \\
\hline 35 & JAC & 0.361 \\
\hline 36 & JSIS & 0.355 \\
\hline 36 & SFM & 0.355 \\
\hline 38 & JAED & 0.350 \\
\hline 39 & OBHDP & 0.338 \\
\hline 40 & IJEC & 0.319 \\
\hline 41 & MA & 0.318 \\
\hline 42 & IBM & 0.302 \\
\hline 43 & CAR & 0.290 \\
\hline 44 & ACMT & 0.285 \\
\hline 45 & JAAF & 0.281 \\
\hline 46 & ACMCS & 0.280 \\
\hline 47 & JSM & 0.271 \\
\hline 48 & AEJ & 0.255 \\
\hline 49 & AA & 0.254 \\
\hline 50 & DB & 0.244 \\
\hline & & \\
\hline
\end{tabular}

\begin{tabular}{|c|c|c|}
\hline Rank & Journal & Score \\
\hline 51 & HCI & 0.238 \\
\hline 52 & INTER & 0.218 \\
\hline 53 & JAL & 0.213 \\
\hline 54 & JAIS & 0.211 \\
\hline 55 & OS & 0.201 \\
\hline 55 & SMR & 0.201 \\
\hline 57 & ABR & 0.196 \\
\hline 57 & IJMMS & 0.196 \\
\hline 57 & MAR & 0.196 \\
\hline 60 & JAE & 0.185 \\
\hline 61 & BIT & 0.180 \\
\hline 62 & CPA & 0.175 \\
\hline 63 & OMEG & 0.169 \\
\hline 64 & AJIS & 0.165 \\
\hline 64 & IRMJ & 0.165 \\
\hline 66 & ACMSIG & 0.159 \\
\hline 67 & AB & 0.149 \\
\hline 68 & CJ & 0.143 \\
\hline 69 & AMR & 0.137 \\
\hline 69 & ASQ & 0.137 \\
\hline 71 & JCIS & 0.132 \\
\hline 71 & AMA & 0.132 \\
\hline 73 & MAJ & 0.117 \\
\hline 74 & EJOR & 0.111 \\
\hline 75 & BAR & 0.106 \\
\hline & & \\
\hline
\end{tabular}

Based on the composite scoring, the Journal of Information Systems (JIS) received the highest score from the respondents. MIS Quarterly (MISQ), International Journal of AIS (IJAIS), and Decision Sciences (DS) ranked second, third and forth respectively. The Accounting Review ranked seventh demonstrating that it is respected among AIS professors even though the focus of the journal is more on financial accounting theory. 
Table 12: AIS Journals with Recognition of at Least $10 \%$ of AACSB Faculty Classified in Tiers (Excluding the Top 10 Inappropriate Journals)

\begin{tabular}{|c|c|c|c|}
\hline Journal Name and Abbreviation & Prestigious & Significant & Creditable \\
\hline Journal of Information Systems (JIS) & 67.1 & & \\
\hline MIS Quarterly (MISQ) & 52.9 & & \\
\hline Decision Sciences (DS) & 28.2 & & \\
\hline International Journal of AIS (IJAIS) & 23.5 & & \\
\hline Journal of MIS (JMIS) & 21.2 & & \\
\hline Management Science (MS) & 18.8 & & \\
\hline Accounting Organizations and Society (AOS) & 17.6 & & \\
\hline IS Research (ISR) & 16.5 & & \\
\hline Communications of the ACM (CACM) & 12.9 & & \\
\hline Auditing: Journal of Practice and Theory (AUD) & & 18.2 & \\
\hline Journal of Accountancy (JA) & & 18.2 & \\
\hline International J. of Intelligent Systems in Acc., Fin. \& Mgt. (IJIS) & & 16.9 & \\
\hline IS Control Journal (ISC) & & 15.1 & \\
\hline IEEE Transactions (various) (IEEET) & & 14.3 & \\
\hline Information Systems Journal (ISJ) & & 13.0 & \\
\hline Decision Support Systems (DSS) & & 11.7 & \\
\hline Review of Business Information Systems (RBIS) & & 11.7 & \\
\hline Behavioral Research in Accounting (BRA) & & 10.4 & \\
\hline Information and Organization (IO) & & 10.4 & \\
\hline CPA Journal (CPAJ) & & & 21.2 \\
\hline Internal Auditor (IA) & & & 18.2 \\
\hline Communications of the AIS (CAIS) & & & 10.6 \\
\hline
\end{tabular}

Finally, Table 12 classifies the journals into Prestigious, Significant and Creditable categories. Once again, the top ten journals ranked not appropriate were excluded from the ranking. Remaining journals with at least $10 \%$ recognition in the category were classified in that particular category. The journals were categorized first as prestigious, second as significant and lastly as creditable. Once a journal was categorized, it was removed from analysis. In other words, a journal could not be placed under more than one category. This method is similar to the one employed by Hotard, Tanner and Manakyan (1996).

Also to be noted is that practitioner journals, such as the Journal of Accountancy (JA), The CPA Journal (CPAJ) and the IS Control Journal (ISC) were respected in the area of AIS. The IS Control Journal (ISC) was ranked $7^{\text {th }}$, the Journal of Accountancy (JA) was ranked $9^{\text {th }}$, and the CPA Journal was ranked $24^{\text {th }}$ under the composite scoring methodology. Under the classification methodology, the Journal of Accountancy, the IS Control Journal and The CPA Journal were also classified as significant and creditable, respectively.

\section{SUMMARY AND CONCLUSIONS}

This research reports the results of a new survey which focuses on AIS journal rankings. Most journal rankings survey professors from diversified areas in accounting. This survey focused only on professors with a specific interest in the areas of AIS or AI/ET. Clearly when IS and AI/ET members of the AAA are asked to classify journals, they produce journal rankings that are significantly different than other studies. This also implies that traditional accounting journal ranking systems may not be appropriate for AIS journals. Faculty working in this specialized area will want to keep abreast of the research done with such journal rankings to keep their publications in desirable outlets.

Table 13 compares the results of this paper with results from other published studies that ranked AIS journals. In the other studies JIS, IJAIS and JMIS never broke into the top ten ranked journals until 2003. In addition to this study, JIS was reported as the top-rated journal by the Doney and Eaton study (2003) and JIS earned the top ranking in a study of AIS faculty preferences at the 2003 AIS Educators Conference (Simkin, Mason, Kerr and Ferrell 
2003). In Table 13 the rankings of JIS, IJAIS and JMIS are verified one more time by respondents at doctorial granting institutions.

It must be noted that even though MISQ, AR, JMIS, MS and ISR are considered top ranked AIS journals, they do not regularly publish AIS research. A review of the Baldwin, Bonie and Scheiner (2000) study divulges that few faculty list publications in these journals on their resumes. This leaves JIS and IJAIS as the outlets that are the most appropriate for AIS researchers. The unique ranking reported in this paper and in other recent studies may be a sign that AIS is developing into a field of study with a distinct identity and a separate body of academic and professional literature.

Table 13: Top 10 Results Compared with Other Published Studies

\begin{tabular}{|c|c|c|c|c|c|c|c|}
\hline $\begin{array}{l}\text { This study, } \\
\text { Overall } \\
\text { Prestigious } \\
\text { Ranking, (2004) }\end{array}$ & \multicolumn{2}{|c|}{$\begin{array}{l}\text { This study, Prestigious } \\
\text { Ranking, Doctorial Granting } \\
\text { Universities, Rank/Percent }\end{array}$} & $\begin{array}{l}\text { Doney \& } \\
\text { Eaton, } 1 \text { to } \\
5 \text { scale, } \\
(2003)\end{array}$ & $\begin{array}{l}\text { Doney \& } \\
\text { Eaton, top } 3 \\
\text { ranked, (2003) }\end{array}$ & $\begin{array}{l}\text { Baldwin, Bonie } \\
\& \text { Scheiner, } \\
\text { frequency on } \\
\text { resumes, (2000) }\end{array}$ & $\begin{array}{l}\text { Daigle \& } \\
\text { Arnold, } \\
\text { (2000) }\end{array}$ & $\begin{array}{l}\text { Arnold, IS } \\
\text { as Primary } \\
\text { Area, (1993) }\end{array}$ \\
\hline 1. JIS & 1. JIS & 63.9 & 1. MISQ & 1. JIS & 1. JA & 1. $\mathrm{AR}$ & 1. JAR \\
\hline 2. MISQ & 2. MISQ & 49.2 & 2. MS & 2. MISQ & 2. IJAIS & 2. JAR & 2. AR \\
\hline 3. IJAIS & 3. IJAIS & 34.4 & 3. DS & 3. IJAIS & 3. JIS & 3. MISQ & 3. MS \\
\hline 4. DS & 4. AR & 16.4 & 4. JIS & 4. DS & 4. CPAJ & 4. ISR & 4. JAE \\
\hline 5. AR & 4. JMIS & 19.7 & 4. ISR & 5. ISR & 4. IA & 5. MS & 5. MISQ \\
\hline 6. JMIS & 6. AOS & 19.7 & 6. CACM & 6. RAIS & 4. ISC & 6. CAR & 6. JF \\
\hline 7. AOS & 6. MS & 18.0 & 7. AUD & 7. IAE & 7. MA & 7. ASQ & 7. DS \\
\hline 8. MS & 8. DS & 18.0 & 8. JMIS & 8. JMIS & 8. IAUD & 8. JAE & 7. AOS \\
\hline 9. ISR & 8. ISR & 16.4 & 9. HBR & 9. MS & 9. IAE & 9. DS & 9. AUD \\
\hline 10. CACM & 10. CACM & 14.8 & 10. JAAF & 10. AH & 9. OGT & 10. AOS & 10. BRA \\
\hline & & & 10. JMAR & & & & \\
\hline
\end{tabular}

\section{SUGGESTIONS FOR FUTURE RESEARCH}

The results presented in this paper could be expanded by increasing the international response rate. Accordingly, the differences in perceptions of American AIS faculty and international AIS faculty could be investigated. Another method for increasing the response rate is to survey the members of other relevant professional organizations such as the AIS Educator Association. One could argue that the responses to this study were bias by a sample selected exclusively from the AAA. However, only two of the top ten prestigious journals reported in this study were AAA journals.

One drawback of this study is that AIS researchers may give favorable scores to the journals they read and publish in and as a result bias the rankings. Perception based rankings may be self-serving and result from predispositions. Therefore, this study could also be extended by attempting to verify the rankings reported in this paper with a citation study that controls for journals that are not appropriate for AIS research. Finally, a study of faculty perceptions of AIS related conferences could supply the profession with valuable information.

\section{REFERENCES}

1. Alreck, P. L. and Robert B. Settle, The Survey Research Handbook, second edition, Irwin, Chicago, IL, 1995.

2. Arnold, V., "Accounting Information Research: Attitudes and Perceptions of Publication Outlets," Advances in Accounting Information Systems, Vol. 2, pp. 133-160, 1993.

3. Baldwin, A. A., B. W. Morris and J. H. Scheiner, "Where do AIS Researchers Publish," International Journal of Accounting Information Systems, Vol. 1, No. 2, pp. 123-134, 2000.

4. Ballas, A. and V. Theoharakis, "Faculty Perceptions and Readership Patterns of Accounting Journals: A Global View," Social Science Research Network, working paper, September 2002. 
5. Brown, L. D. and R. J. Huefner, "The Familiarity with and Perceived Quality of Accounting Journals: Views of Senior Accounting Faculty in Leading U.S. MBA Programs," Contemporary Accounting Research, summer, pp. 223-250, 1994.

6. Cabell, D. W. and D. L. English, Cabell's Directory of Publishing Opportunities in Accounting: eighth edition, 2001-2002. Cabell Publishing Company, Beaumont, Texas, 2000.

7. Campbell, D. R. and R. G. Morgan, "Publication Activity of Promoted Accounting Faculty," Issues in Accounting Education, spring, pp. 28-43, 1987.

8. Christensen, A. L., C. A. Finger and C. K. Latham, "New Accounting Scholars' Publications in Accounting and Non-accounting Journals," Issues in Accounting Education, Vol. 17, No. 3, pp. 233-251, 2002.

9. Coe, R. K. and I. Weinstock, "Evaluating the Accounting Professor's Journal Publications," Journal of Accounting Education, spring, pp. 126-129, 1983.

10. Daigle, R. J. and V. Arnold, “An Analysis of the Research Productivity of AIS Faculty," International Journal of Accounting Information Systems, Vol. 1, No. 2, pp. 106-122, 2000.

11. Dennis, A, “The Journal Selection Process," http://www.terry.uga.edu/ adennis/rankings/select.htm, 2002.

12. Doney, L. D. and T. V. Eaton, "Forums for Accounting Information Systems Scholars," The Review of Business Information Systems, Vol. 7, No. 3, pp. 13-22, 2003.

13. Gelinas, U. J. and S. G. Sutton. Accounting Information Systems, fifth edition, Cincinnati, South-Western and Thomson Learning, Cincinnati, Ohio, 2002.

14. Gray, R., J. Guthrie and L. Parker, "Rites of Passage and the Self-immolation of Academic Accounting Labor: An Essay Exploring Exclusivity Verses Mutuality in Accounting Scholarship," Accounting Forum, March, pp. 1-30, 2002.

15. Johnson, P. M., P. M. J. Reckers, and L. Solomon. "Evolving Research Benchmarks," Advances in Accounting, Vol. 19, pp. 235-243, 2002.

16. Judd, C. M., E. R. Smith, and L. H. Kidder. Research Methods in Social Relations, sixth edition. Holt, Rinehart and Winston, London, UK, 1991.

17. Keller, Gerald and Brian Warrack, Statistics for Management and Economics, sixth edition, South-Western and Thompson Learning, London, UK, 2003.

18. Kohler, Heinz, Statistics for Business and Economics, South-Western and Thompson Learning London, UK, 2002.

19. Hasselback, J. R., Accounting Faculty Directory 2004-2005, Prentice Hall, Upper Saddle River, NJ, 2004.

20. Hotard, D., J. Tanner and H. Manakyan, "Management Faculty Ratings of Journal Quality: The Factors and the Journals," Southern Business Review, spring, pp. 8-20, 1996.

21. Howard, T. P. and L. A. Nikolai, "Attitude Measurement and Perceptions of Accounting Faculty Publication Outlets" The Accounting Review, October, pp. 765-776, 1983.

22. Hull, R.P. and G.B. Wright, "Faculty Perception of Journal Quality: An Update," Accounting Horizons, March, pp. 77-98, 1990.

23. Judd, C. M., E.R. Smith, and L.H. Kidder, Research Methods in Social Relations, sixth edition, The Dryden Press, Chicago, IL, 1991.

24. Margolis, J., "Citation Indexing and Evaluation of Scientific Papers”, Science, March, pp. 1213-1219, 1967.

25. Mason, P.M., J.W. Steagall, and M.M. Fabritius, "Economics Journal Rankings by Type of School:

Perceptions versus Citations," Quarterly Journal of Business and Economics, winter, pp. 69-79, 1997.

26. May, K.O., “Abuses of Citation Indexing”, Science, May, pp. 890-892, 1967.

27. McNulty, J.E. and J. Beokeloo, "Two Approaches to Measuring Journal Quality: Application to Finance Journals," Journal of Economics and Finance, spring, pp. 30-38, 1999.

28. Milne, R.A. and G.A. Vent, "Publication Productivity: A Comparison of Accounting Faculty Members Promoted in 1981 and 1984," Issues in Accounting Education, spring, pp. 94-102, 1987.

29. Mylonopoulos, N. and V. Theoharakis, "Global Perceptions of IS Journals," Communications of the ACM, September, pp. 29-33, 2001.

30. Read, W.J., D.V. Rama, and K. Raghunandan, Are Publication Requirements for Accounting Faculty Promotions Still Increasing?" Issues in Accounting Education, May, pp. 327-339, 1998. 
31. Samuels, J. A. and P. J. Steinbart, "The Journal of Information Systems: A Review of the First 15 Years," Journal of Information Systems, fall, pp. 97-116, 2002.

32. Schroeder, R. G., D. D. Payne, and D. G. Harris, "Perceptions of Accounting Publication Outlets: A Further Analysis," The Accounting Educators' Journal, fall. Pp. 1-17, 1988.

33. Simkin, MG, R. Mason, S. Kerr and B. Ferrell, "A Profile of Accounting Information Systems Faculty," AIS Educators Association Conference Papers and Abstracts, June, 2003.

34. Stone, D. N., "Researching the Revolution: Prospects and Possibilities for the Journal of Information Systems," Journal of Information Systems, spring, pp. 1-6, 2002.

35. Virgo, J. A., "A Statistical Procedure for Evaluating the Importance of Scientific Papers," The Library Quarterly, October, pp. 415-430, 1977.

36. Woodward, A. M. and S. Henson, "Citation to Review Serials," Journal of Documentation, December, pp. 290-294, 1976.

37. Zeff, S. A., "A Study of Academic Research Journals in Accounting," Accounting Horizons, September, pp. 158-167, 1996.

38. Zimmerman, J. L., "Can American Business Schools Survive?” The Bradley Policy Research Center, working paper no. FR 01-16, September 2001.

39. Zivney, T. L. and W. J. Bertin. "Publish or Perish: What the Competition is Really Doing," The Journal of Finance, March, pp. 295-329, 1992.

Appendix 1: Journal Abbreviations

\begin{tabular}{|c|c|}
\hline Abacus (AB) & International J. of AIS (IJAIS) $^{1}$ \\
\hline Academy of Acc. and Financial Studies J. (AAFS) & \begin{tabular}{|l} 
International J. of Intelligent Sys. in Acc., Fin., \& Mgt. (IJIS) \\
\end{tabular} \\
\hline Academy of Management (AM) & International J. of Digital Acc. Research (IJDAR) \\
\hline Academy of Management Review (AMR) & International Journal of E-Commerce (IJEC) \\
\hline Accountancy (ACC) & International Journal of H-C Studies (IJHCS) \\
\hline Accounting and Business Research (ABR) & \begin{tabular}{|l} 
International J. of Man-Machine Studies (IJMMS) \\
\end{tabular} \\
\hline Accounting Educator's Journal (AEJ) & International Tax Journal (ITJ) \\
\hline Accounting Education: International Journal (AEIJ) & IS Audit and Control Journal (ISAC) \\
\hline Accounting Enquiries (AE) & IS Control Journal (ISC) $^{4}$ \\
\hline Accounting Forum (AF) & IS Research (ISR) \\
\hline Accounting Historians Journal (AHJ) & Issues in Accounting Education (IAE) \\
\hline Accounting Horizons (AH) & IT and People (ITP) \\
\hline Acc., Management and Info. Technologies (AMIT) & Journal of the ACM (JACM) \\
\hline Accounting Research Journal (ARJ) & Journal of the Association of IS (JAIS) \\
\hline Accounting Review (AR) & Journal of CIS (JCIS) \\
\hline Accounting, Organizations and Society (AOS) & Journal of MIS (JMIS) \\
\hline ACM Computing Surveys (ACMCS) & Journal of Accountancy (JA) \\
\hline ACM SIG Publications (ACMSIG) & Journal of Accounting and Computers (JAC) \\
\hline ACM Transactions (various) (ACMT) & Journal of Accounting and Economics (JAE) \\
\hline Administrative Science Quarterly (ASQ) & Journal of Accounting and Public Policy (JAPP) \\
\hline Advances in Accounting (AA) & Journal of Accounting Case Research (JACR) \\
\hline Advances in Acc. Behavioral Research (AABR) & Journal of Accounting Education (JAED) \\
\hline Advances in International Accounting (AIA) & Journal of Accounting Literature (JAL) \\
\hline Advances in Management Accounting (AMA) & Journal of Accounting, Auditing \& Finance (JAAF) \\
\hline Advances in Taxation (AT) & Journal of Accounting Research (JAR) \\
\hline $\begin{array}{l}\text { Application of Fuzzy Logic and the Theory of Evidence in } \\
\text { Acc. (AFLT) }\end{array}$ & Journal of American Tax Association (JATA) \\
\hline Auditing: Journal of Practice and Theory (AUD) & Journal of Business, Finance and Acc. (JBFA) \\
\hline Australian Journal of IS (AJIS) & Journal of Corporate Taxation (JCT) \\
\hline Behavior and Information Technology (BIT) & Journal of Emerging Topics in Accounting (JETA) \\
\hline Behavioral Research in Accounting (BRA) & Journal E-U Computing (JEUC) \\
\hline British Accounting Review (BAR) & J. of International Acc., Auditing and Tax (JIAAT) \\
\hline CA Magazine (CA) & Journal of Information Systems (JIS) \\
\hline Communications of the ACM (CACM) & J. of Management Information Systems (JMIS) \\
\hline CMA Magazine (CMA) & J. of Management Accounting Research (JMAR) \\
\hline
\end{tabular}




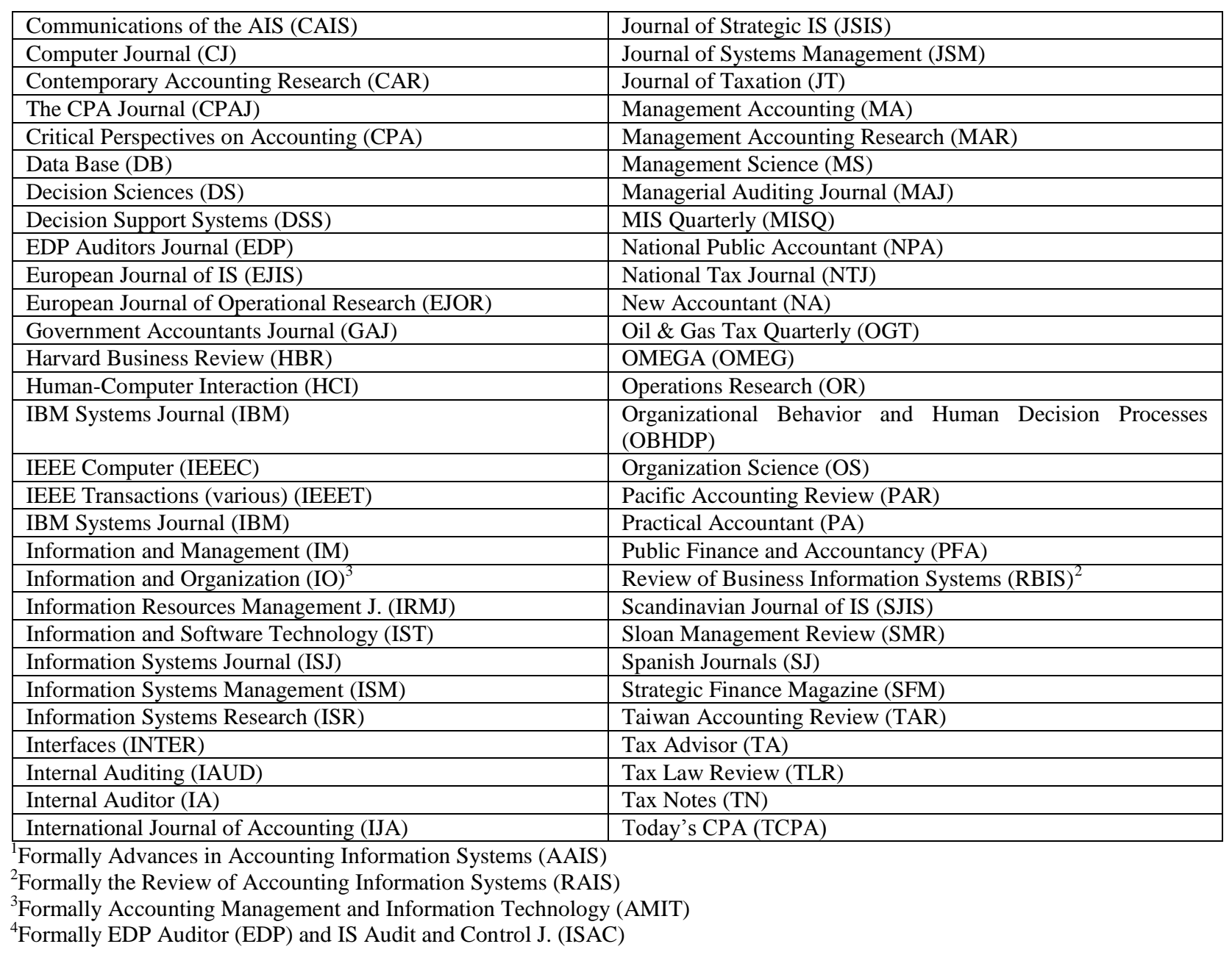

